overstocking, and concentration of sheep in the same paddocks for years. Incidentally, Dr. Ealey tells the origin of the name kangaroo. When Captain Cook asked the aborigines the name of the animal they replied, "Canguru," meaning "What are you talking about ?"

Visiting the island of Martinique in the West Indies in quest of a snakewhich he failed to find-Dr. Herndon G. Dowling, curator of reptiles in the New York Zoo, was struck by the apparent absence of native animal

\section{Why \\ Martinique \\ Lacks Wild Birds} life, with few species of small birds, and no large birds at all. But, "mornings and evenings, along the roadside brush and hedgerows, small boys could be seen searching the trees and bushes. Armed with small-bore rifles, alone or in groups of three to five, the boys were scouring the countryside for any bird, no matter how small, that might be added to the dinner pot." Martinique, as he puts it, suffers from a "prevalence of people". There are 290,000 in 385 square miles. Even in the very steep and rugged mountains the native wildlife "seemed virtually gone", the forests silent and still. The area where the endemic Martinique trembler was thought to survive he found cultivated with sugarcane and thick with people. But the peninsula where the white-breasted thrasher is thought to survive was still relatively wild and suitable for a reserve.

A landowner in the home counties encouraged a friend to form a shooting syndicate on his land and rear pheasants, hoping in this way to reduce the numbers of armed trespassers and foxes, also rabbits and pigeons. With the first two he succeeded, but not with the others.

The Result "Rabbits and rats are now increasing at an alarming of Killing rate and the various people who used to shoot my All Predators pigeons seem now to have disappeared." Moreover, a neighbour reports that two pairs of barn owls have disappeared from his buildings, and the little owls that used to forage for mice behind his plough have also not turned up. The landowner is inclined to think he was better off before. "I have pretty well decided," he concludes, "to get rid of the syndicate." The trouble is, of course, the syndicate's attitude to so-called "vermin"; this is what happens when all predators are destroyed. An account of the discussions on the role of mammal predators in the British countryside, at the Symposium in March organised by the FPS and the Council for Nature, will appear in the next issue of ORYX.

\title{
THE LEOPARD COATS
}

NCE in a moment of great generosity God has shown to me

A leopard running free.

How, from that moment, could he expect of me, Born without his tolerance, calmly to see

All those women, those bloody awful women, Dressed up in leopard skins and sitting down to tea?

By Vernon Bartlett, quoted from the New Statesman by kind permission. 